\title{
Effect of thermal modification on the technological properties of wood from species in an agroforestry system
}

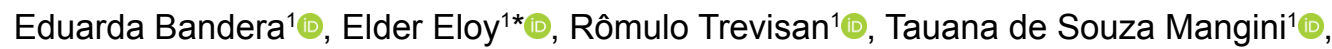 \\ Laura da Silva Zanchetta ${ }^{1} \odot$, Luana Candaten ${ }^{1} \odot$, Nillar Elvira Pereira Azevedo'스, Yuri Cezar Tessaro Santos ${ }^{1} \odot$ \\ 1 Universidade Federal de Santa Maria, Frederico Westphalen, RS, Brasil. E-mail: duda_bandera@outlook.com; eloyelder@yahoo.com.br; romulo_trevisan@yahoo.com.br; \\ tauanamangini@yahoo.com; zanchettalaura2@gmail.com; luana_candaten@outlook.com; nillarpereira@hotmail.com; vishyuricts2@gmail.com
}

ABSTRACT: This work aims to evaluate the effect of thermal modification on the physical and mechanical properties of species of wood, from an agroforestry system. The species evaluated were Parapiptadenia rigida (Benth.) Brenan, Peltophorum dubium (Spreng.) Taub., Eucalyptus grandis $\times$ Eucalyptus urophylla and Schizolobium parahyba (Vell.) Blake, aged nine. The specimens were submitted to thermal treatments $\left(120,150,180\right.$ and $\left.210^{\circ} \mathrm{C}\right)$, in addition to the control samples. For the mechanical properties, the modules of elasticity and rupture, tension in the proportional limit and maximum force were evaluated according to ASTM D 143-94. For the physical properties of basic density and shrinkage, the evaluation took place according to NBR 7190 . The thermal treatment modified the mechanical properties of the wood in a positive way up to $180^{\circ} \mathrm{C}$, with the highest values being observed for $E$. grandis $\times E$. urophylla and P. rigida. Likewise, the heat treatment has modified the physical properties of wood retractability in a positive way up to $210^{\circ} \mathrm{C}$, with the anisotropic coefficient decreasing with increasing temperature. Thus, it is concluded that the thermal modification alters the physical and mechanical properties of the four analyzed species. Furthermore, it is perceived that for the case of mechanical characteristics these changes are positive up to a temperature of $180^{\circ} \mathrm{C}$, while for the physical ones the best results are found at a temperature of $210^{\circ} \mathrm{C}$.

Key words: basic density; mechanical resistance; retractability

\section{Efeito da modificação térmica nas propriedades tecnológicas da madeira de espécies de um sistema agroflorestal}

RESUMO: Este trabalho teve como objetivo avaliar o efeito da modificação térmica nas propriedades físicas e mecânicas de madeira de espécies, provenientes de um sistema agroflorestal. As espécies avaliadas foram a Parapiptadenia rigida (Benth.) Brenan, Peltophorum dubium (Spreng.) Taub., Eucalyptus grandis x Eucalyptus urophylla e Schizolobium parahyba (Vell.) Blake, com nove anos de idade. Os corpos de prova foram submetidos a tratamentos térmicos $\left(120,150,180\right.$ e $\left.210^{\circ} \mathrm{C}\right)$, além das amostras controle. Para as propriedades mecânicas foram avaliados os módulos de elasticidade e ruptura, tensão no limite proporcional e força máxima de acordo com a ASTM D 143-94. Para as propriedades físicas de massa específica básica e de retratibilidade a avaliação ocorreu de acordo com a NBR 7190. O tratamento térmico modificou as propriedades mecânicas da madeira de uma forma positiva até os $180^{\circ} \mathrm{C}$, sendo que os maiores valores foram observados para $E$. grandis $\times E$. urophylla e $P$. rigida. Da mesma forma, o tratamento térmico modificou as propriedades físicas de retratibilidade da madeira de uma forma positiva até os $210^{\circ} \mathrm{C}$, sendo que o coeficiente anisotrópico diminui com o aumento da temperatura. Assim, conclui-se que a modificação térmica altera as propriedades físico-mecânicas das quatro espécies analisadas. Ainda, percebe-se que para as características mecânicas essas alterações são positivas até a temperatura de $180^{\circ} \mathrm{C}$, enquanto que, para as físicas são encontrados os melhores resultados na temperatura de $210^{\circ} \mathrm{C}$.

Palavras-chave: massa específica; resistência mecânica; retratibilidade

*Elder Eloy - E-mail: eloyelder@yahoo.com.br (Corresponding author)

Associate Editor: Rafael Rodolfo de Melo 


\section{Introduction}

Over the years, we have seen an increase in the implementation of new scenarios in the timber field, among them the agroforestry systems (SAF's), which are characterized by a complex production set, associating individuals from different cycles, which promotes the integration of various timber species and the supply of the demand imposed by the industry.

In this process, the aim is to use fast-growing trees with physical-mechanical properties that are appropriate for the various uses, such as high strength and flexibility. With this, some genera, native and exotic, have been highlighted, such as Eucalyptus, Parapiptadenia, Peltophorum, and Schizolobium, for having desired characteristics for use in various purposes.

The vast use of wood is due to the advantages of the material for application in works, among these, in civil construction, since it is a natural polymer that has structural function and also organoleptic and technological characteristics that vary according to the exposure environment (Paula et al., 2016). One of the biggest challenges in the field of wood technology has been finding resources to make it possible to control dimensional change and product durability (Gallio et al., 2019). Therefore, the evaluation of the wood's properties becomes of utmost importance for the proper use and quality in the final piece.

In order to increase the natural durability and improve the appearance of species of low economic value, the use of heat treatment is performed, which aims to modify the physical and mechanical characteristics of the wood (Schulz et al., 2020). The procedure is based on submitting the wood to high temperatures, which can range from 100 to $220^{\circ} \mathrm{C}$ (Modes et al., 2017), and in Brazil it is not used on a large scale, despite the benefits proven by major applicators, among these, Europe (Poubel et al., 2015).

Thus, the thermal treatment stands out in some points when compared to the others, among these, the non-use of substances that are toxic to the environment and the reduced cost (Carvalho et al., 2019). In addition to improving the properties of wood, the use of thermal modification seeks to increase the quality, valuation of the product and, consequently, the expansion of possibilities of use after the useful period, when contrasted with other methods of treatment (Paes et al., 2016). However, in contrast, it is reported that the elevation in the treatment temperature can lead to a reduction in the mechanical properties that make up the material (Poubel et al., 2015).

Wood possesses numerous technological properties, with specific mass, shrinkage, and mechanical strength, considered determining indicators when it comes to the solid material (Trevisan et al., 2016). Thus, the association of factors that make up the characteristics cited, such as the morphological, anatomical, and chemical constitution, imply directly in the behavior of the material during industrial procedures.

Thus, by providing several improvements and increasing the range of use of heat-treated wood, it is necessary to study the influence of the procedure on the many peculiarities of the material. Therefore, the present work aimed to evaluate the effect of thermal modification on the physical and mechanical wood properties of species from an agroforestry system.

\section{Materials and Methods}

\section{Place of the experiment}

The material used in the present study came from an agroforestry system belonging to the Universidade Federal de Santa Maria, Campus Frederico Westphalen (UFSM/FW), Rio Grande do Sul, Brazil, at $27^{\circ} 22^{\prime \prime}$ S; $53^{\circ} 25^{\prime \prime}$ W, at $480 \mathrm{~m}$ altitude. Also, according to the Köppen classification, the predominant climate of the region is $\mathrm{Cfa}$, characterized as sub-humid subtemperate, with an average annual temperature of $18.8^{\circ} \mathrm{C}$ and an average temperature of the coldest month of $13.3^{\circ} \mathrm{C}$. For the development of the work, the forest species analyzed were Parapiptadenia rigida (Benth.) Brenan, Peltophorum dubium (Spreng.) Taub., Eucalyptus grandis $\times$ Eucalyptus urophylla and Schizolobium parahyba (Vell.) Blake.

\section{Sampling and evaluation}

The sampling process consisted of felling three trees of each species, which were approximately nine years old. From each individual, a log two meters long was removed from the position of the diameter at breast height (DBH) and then the central planks were made and the specimens were subsequently produced.

The evaluations were carried out in the Wood Technology Laboratory at UFSM/FW. For the estimation of static bending, specimens with the dimensions $2.5 \times 2.5 \times 41 \mathrm{~cm}$ (width $\mathrm{x}$ thickness $x$ length) were produced, taking into consideration some criteria such as anatomical orientation and sizing. Thirty samples per species were separated and identified, totaling 120 specimens.

For the implementation of the thermal modification, a forced air circulation oven was used at temperatures: 120,150, 180 , and $210^{\circ} \mathrm{C}$, over a period of four hours. Six repetitions were done for each treatment, including the control. After this procedure, the samples were submitted to the static bending test, performed in a universal testing machine (EMIC), model DL-2000, adopting ASTM D 143-94 (ASTM, 2000), generating values of modulus of elasticity (MOE) and rupture (MOR), maximum force (MF), and tension at the proportional limit (TPL).

To evaluate shrinkage, the samples were made in the dimensions: $2.5 \times 2.5 \times 5 \mathrm{~cm}$ (width $\mathrm{x}$ thickness $\mathrm{x}$ length), according to NBR 7190 (ABNT, 1997). The samples were weighed on a precision balance of $0.01 \mathrm{~g}$, and their dimensions were checked with a digital pachymeter, accurate to $0.01 \mathrm{~mm}$, at marked and identified points on the samples. After this step, the samples were immersed in water until the fiber was completely saturated, in order to obtain the weights and the dimensional variation, both saturated. From this, it was possible to indicate the swelling values in the longitudinal, tangential, and radial planes, due to the heat treatments employed.

The saturated specimens were exposed to air drying for 30 days, and then placed in an oven with forced air circulation 
at $103{ }^{\circ} \mathrm{C}$ until they reached a constant weight. The weight and dimension values were collected again to perform the shrinkage calculations for the species studied and the treatments applied, in the longitudinal, tangential, and radial planes. To obtain the coefficient of anisotropy, the data collected only for the tangential and radial planes and the treatments employed were taken into consideration.

After performing all the procedures, data from the saturated dimensions and dry weight at $103{ }^{\circ} \mathrm{C}$ of the specimens were used to determine the basic density of the different species in accordance with NBR 7190 (ABNT, 1997), the volume being determined by the stereometric method and the weight by averages of a $0.01 \mathrm{~g}$ precision balance.

\section{Experimental design and data analysis}

For the statistical analysis of the data an entirely randomized design was used, characterized by a $4 \times 5$ factorial arrangement, with four forest species and five heat treatments, with six repetitions. The data were submitted to statistical analysis using the Statistical Analysis System Software (SAS, 2003), in which analysis of variance, $F$ test, analysis to verify normality of the data using the ShapiroWilk test and heteroscedasticity using Bartlet test to verify homogeneity of variance, and the Tukey test of averages at $5 \%$ error probability were performed.

\section{Results and Discussion}

From the analysis of variance, it can be observed that the heat treatment significantly modified the mechanical properties of the four species studied, noting that up to the temperature of $180{ }^{\circ} \mathrm{C}$ there were improvements in the characteristics (Table 1). The MOR showed a reduction for all species analyzed, especially between the temperatures of 150 and $210^{\circ} \mathrm{C}$. For this same variable, it can be seen that the wood of $P$. rigida stood out in relation to the others, presenting the highest values for the corresponding property.

In general, the reduction in the MOR property indicates that the thermal process generates a more pronounced decrease in hemicellulose content, since the reduction of this polymer is one of the main causes for the loss of strength (Gallio et al., 2019). Other authors (Poubel et al., 2015; Paneque et al., 2016; Modes et al., 2017; Mbamu et al., 2020) also state this behavior, explaining that the decrease in mechanical strength is related to the mass loss resulting from the applied heat treatment.

The MOE results did not differ statistically between the control and the exposure to $210{ }^{\circ} \mathrm{C}$ temperature (Table 1 ). Overall, the highest value was found for the $E$. grandis $\times E$. urophylla hybrid, where it was $12000.64 \mathrm{MPa}$. Concomitantly, Ferreira et al. (2019) stated that for species treated at temperatures up to $200{ }^{\circ} \mathrm{C}$ for a period of four hours, the mechanical properties remained with values close to the original ones.

A contradictory result to that observed in the present research for MOE property was reported by Silva et al. (2015), in which they reported that thermal modification caused a decrease in the mechanical properties of wood. In counterpoint, Esteves \& Pereira (2009) observed that MOE was less susceptible to the effect of temperature when compared to MOR, coming to the conclusion that this is associated with the role of cell wall constituents in these properties.

Table 1. Average static bending values of the mechanical properties of wood exposed to different thermal modification treatments.

\begin{tabular}{|c|c|c|c|c|c|}
\hline \multirow{2}{*}{ Species } & \multicolumn{5}{|c|}{ Treatment } \\
\hline & Control & $120^{\circ} \mathrm{C}$ & $150^{\circ} \mathrm{C}$ & $180^{\circ} \mathrm{C}$ & $210^{\circ} \mathrm{C}$ \\
\hline & \multicolumn{5}{|c|}{ MOR (MPa) } \\
\hline P. rigida & $85.31 \mathrm{cA}$ & $110.94 \mathrm{abA}$ & $121.00 \mathrm{aA}$ & $103.83 \mathrm{bA}$ & $57.00 \mathrm{dA}$ \\
\hline P. dubium & $65.03 \mathrm{abB}$ & $62.24 \mathrm{abB}$ & $74.67 \mathrm{aC}$ & $52.04 \mathrm{bC}$ & $34.83 \mathrm{cB}$ \\
\hline E. grandis $\times$ E. urophylla & $89.26 \mathrm{bA}$ & $110.19 \mathrm{aA}$ & $91.35 \mathrm{bB}$ & $87.39 \mathrm{bB}$ & $47.20 \mathrm{cAB}$ \\
\hline \multirow[t]{2}{*}{ S. parahyba } & $30.86 \mathrm{aC}$ & $36.97 \mathrm{aC}$ & $35.84 \mathrm{aD}$ & $29.50 \mathrm{aD}$ & $9.09 \mathrm{bC}$ \\
\hline & \multicolumn{5}{|c|}{ MOE (MPa) } \\
\hline P. rigida & $6113.20 \mathrm{aB}$ & $6787.05 \mathrm{aB}$ & $7290.66 \mathrm{aB}$ & $6830.32 \mathrm{aB}$ & $7335.00 \mathrm{aB}$ \\
\hline P. dubium & $6948.11 \mathrm{aB}$ & $6079.71 \mathrm{aB}$ & $6743.14 \mathrm{aB}$ & $6088.41 \mathrm{aB}$ & $6347.21 \mathrm{aB}$ \\
\hline E. grandis $\times$ E. urophylla & $10304.14 \mathrm{bA}$ & $11767.42 \mathrm{abA}$ & $11180.67 \mathrm{abA}$ & $12000.64 \mathrm{aA}$ & $10535.45 \mathrm{abA}$ \\
\hline \multirow[t]{2}{*}{ S. parahyba } & $3094.99 \mathrm{aC}$ & $3589.99 \mathrm{aC}$ & $3544.68 \mathrm{aC}$ & $3435.19 \mathrm{aC}$ & $2617.96 \mathrm{aC}$ \\
\hline & \multicolumn{5}{|c|}{ TPL (MPa) } \\
\hline P. rigida & $36.80 \mathrm{cB}$ & $42.41 \mathrm{bcB}$ & $47.79 \mathrm{abB}$ & $49.21 \mathrm{aB}$ & $49.01 \mathrm{abA}$ \\
\hline P. dubium & $35.12 \mathrm{bB}$ & $33.85 \mathrm{bC}$ & $43.09 \mathrm{aB}$ & $37.07 \mathrm{abc}$ & $33.16 \mathrm{bB}$ \\
\hline E. grandis $\times$ E. urophylla & $57.41 \mathrm{bA}$ & $71.47 \mathrm{aA}$ & $59.44 \mathrm{bA}$ & $58.57 \mathrm{bA}$ & $45.52 \mathrm{cA}$ \\
\hline \multirow[t]{2}{*}{ S. parahyba } & $19.31 \mathrm{aC}$ & $20.06 \mathrm{aD}$ & $22.61 \mathrm{aC}$ & $24.80 \mathrm{aD}$ & $8.48 \mathrm{bC}$ \\
\hline & \multicolumn{5}{|c|}{$\mathrm{MF}(\mathrm{N})$} \\
\hline P. rigida & $2430.48 \mathrm{bAB}$ & 3253.36 aA & $3448.02 \mathrm{aA}$ & $2671.82 \mathrm{bA}$ & $1517.09 \mathrm{cA}$ \\
\hline P. dubium & $2138.05 \mathrm{aB}$ & $1933.58 \mathrm{aB}$ & $2171.19 \mathrm{aC}$ & $1487.57 \mathrm{bB}$ & $939.97 \mathrm{cB}$ \\
\hline E. grandis $\times$ E. urophylla & $2730.86 \mathrm{abA}$ & 2951.61 aA & $2747.33 \mathrm{abB}$ & $2405.28 \mathrm{bA}$ & $1298.69 \mathrm{CAB}$ \\
\hline S. parahyba & $952.03 \mathrm{aC}$ & $1055.88 \mathrm{aC}$ & $1010.38 \mathrm{aD}$ & $915.74 \mathrm{aC}$ & 272.13 bC \\
\hline
\end{tabular}

Where: MOE: Modulus of Elasticity (MPa); MOR: Modulus of Rupture (MPa); TPL: Tension at the Proportional Limit (MPa); MF: Maximum Force (N). Averages followed by lower case letters in the row compare temperature treatments, and averages followed by upper case letters in the columns compare species, according to Tukey test at $5 \%$ error probability. 
In addition, an increase in the value of MOR and MOE was observed in the first treatments applied for all species evaluated with the exception of $P$. dubium. This initial increase may be correlated to the condensation processes of lignin and cellulose, thus new chemical bonds are formed resulting in the elevation of the values of both properties (Modes et al., 2017).

Regarding the TPL and MF properties, both showed discontinuity of the values with increasing temperature (Table 1). The same was obtained by Fontoura et al. (2015), who in their study of Hovenia dulcis, found an oscillation with no stabilization trend, when they subjected the samples for a period of four hours at temperatures of $100,120,140,160$, and $180^{\circ} \mathrm{C}$ and control. In the analysis performed by Cademartori et al. (2012), for $E$. grandis, the results did not corroborate with those of this research, in which they obtained a gradual decrease in the values for the MF property when temperatures of $180,200,220$, and $240^{\circ} \mathrm{C}$ and control were used.

As for the effect of thermal modification in relation to shrinkage, it was observed that in the longitudinal direction the variations were smaller when compared to the other directions (Table 2). In addition, for the radial and tangential positions the best results are obtained when the samples are submitted to $210^{\circ} \mathrm{C}$.

This occurs because wood is an anisotropic material, causing dimensional variations in the transverse direction (tangential and radial) to be greater than in the longitudinal direction, because a large part of the cells are oriented longitudinally (Cezaro et al., 2016). However, comparing the transverse directions, it can be stated that the radial varies less than the tangential because of the radii and the presence of punctuations, which are present on the radial walls of the fibers and tracheoids, causing a deviation of the cellulose microfibrils in the S2 layer (Ferreira et al., 2019).

In addition, for the control treatment, the tangential and radial contractions of $P$. dubium and S. parayba species had the lowest values. For Cezaro et al. (2016), this occurrence can be attributed to the low values of the basic density for the respective species, which corroborates the results of this work (Table 3).

The highest average value of the basic specific mass obtained was $0.652 \mathrm{~g} \mathrm{~cm}^{-3}$ equivalent to the species $P$. rigida, followed by $0.509 \mathrm{~g} \mathrm{~cm}^{-3}$ for the hybrid E. grandis $\times$ E. urophylla (Table 3). The result presented for P. rigida is in agreement with that reported in the literature by Souza et al. (2017), reporting a value of $0.683 \mathrm{~g} \mathrm{~cm}^{-3}$. However, in the case of $E$. grandis $\times E$. urophylla, the average was higher than that found by Eleotério et al. (2015), who presented a value of $0.405 \mathrm{~g} \mathrm{~cm}^{-3}$.

The difference in the values found for the basic density is due to the biological characteristics of each tree, genotypeenvironment interaction, and the place of growth (Rocha et al., 2016). The highest density values can also be explained by unfavorable environments for the plant, while the lowest are found in trees exposed to environments that favor its physiological activity (Zaque et al., 2018). According to Braz et al. (2015), the basic density exerts influence on several other wood properties, such as those studied in the present research: shrinkage, swelling, mechanical and thermal properties.

The longitudinal, tangential and radial swelling, showed significant differences between the species and temperatures

Table 2. Average values of shrinkage and anisotropic coefficient of four analyzed species submitted to thermal modification treatment.

\begin{tabular}{|c|c|c|c|c|c|}
\hline \multirow{2}{*}{ Species } & \multicolumn{5}{|c|}{ Treatment } \\
\hline & Control & $120^{\circ} \mathrm{C}$ & $150^{\circ} \mathrm{C}$ & $180^{\circ} \mathrm{C}$ & $210^{\circ} \mathrm{C}$ \\
\hline & \multicolumn{5}{|c|}{$\beta \operatorname{Lg}(\%)$} \\
\hline$P$. rigida & $0.91 \mathrm{abAB}$ & $1.09 \mathrm{bB}$ & $1.02 \mathrm{abB}$ & $0.81 \mathrm{aB}$ & $0.86 \mathrm{abB}$ \\
\hline E. grandis $\times E$. urophylla & $0.69 \mathrm{aA}$ & $0.69 \mathrm{aA}$ & 0.68 aA & $0.52 \mathrm{aA}$ & $1.61 \mathrm{bc}$ \\
\hline S. parahyba & $0.99 \mathrm{cB}$ & $0.75 \mathrm{bcA}$ & $0.58 \mathrm{abA}$ & $0.44 \mathrm{aA}$ & $0.74 \mathrm{bcB}$ \\
\hline P. dubium & $6.29 \mathrm{bA}$ & $5.54 \mathrm{bA}$ & $6.12 \mathrm{bA}$ & $6.52 \mathrm{bB}$ & $3.80 \mathrm{aA}$ \\
\hline E. grandis $\times E$. urophylla & $9.33 \mathrm{bB}$ & $8.96 \mathrm{bc}$ & $8.41 \mathrm{bB}$ & $8.87 \mathrm{bc}$ & $6.68 \mathrm{aB}$ \\
\hline \multirow[t]{2}{*}{ S. parahyba } & $5.88 \mathrm{bcA}$ & $6.92 \mathrm{cB}$ & $5.54 \mathrm{bA}$ & $5.34 \mathrm{bA}$ & $3.95 \mathrm{aA}$ \\
\hline & \multicolumn{5}{|c|}{$\beta R d(\%)$} \\
\hline P. rigida & $5.55 \mathrm{bc}$ & $4.05 \mathrm{aB}$ & $4.08 \mathrm{aB}$ & $4.54 \mathrm{aB}$ & $3.98 \mathrm{aC}$ \\
\hline P. rigida & $1.92 \mathrm{aA}$ & $2.34 \mathrm{bB}$ & $2.01 \mathrm{aAB}$ & $2.19 a b B$ & $1.99 \mathrm{aA}$ \\
\hline P. dubium & $2.14 \mathrm{aA}$ & $1.94 \mathrm{aA}$ & $2.16 \mathrm{aB}$ & $2.07 \mathrm{aAB}$ & $2.05 \mathrm{aA}$ \\
\hline E. grandis $\times E$. urophylla & $1.98 \mathrm{abA}$ & $1.97 \mathrm{abA}$ & $1.84 \mathrm{abA}$ & $1.80 \mathrm{aA}$ & $2.13 \mathrm{bA}$ \\
\hline S. parahyba & $1.95 \mathrm{aA}$ & $1.95 \mathrm{aA}$ & $1.85 \mathrm{aA}$ & $2.13 \mathrm{aB}$ & $1.97 \mathrm{aA}$ \\
\hline
\end{tabular}

Where: $\beta$ Lg: Longitudinal Shrinkage (\%); $\beta$ Tg: Tangential Shrinkage (\%); $\beta$ Rd: Radial Shrinkage (\%); Caß: Anisotropic Shrinkage Coefficient. Lower case letters in the row compare temperature treatments and upper case letters in the columns compare species, according to Tukey test at $5 \%$ error probability. 
Table 3. Average values of basic density $(\rho b)$ of the witness of the different species analyzed.

\begin{tabular}{lc}
\hline \multicolumn{1}{c}{ Species } & $\rho_{\mathrm{b}}\left(\mathrm{g} \mathrm{cm}^{-3}\right)$ \\
\hline$P$. rigida & 0.652 \\
$P$. dubium & 0.488 \\
E. grandis $\times$ E. urophylla & 0.509 \\
S. parahyba & 0.277 \\
\hline
\end{tabular}

(Table 4). The lowest values, although not significant for some species when compared between the control and the submission to maximum temperature, were found in the samples exposed to the treatment at $210^{\circ} \mathrm{C}$. In this way, it is evident that the thermal modification process results in less water absorption after thermal treatment, causing an improvement in the dimensional stability of the specimen.

Similar behavior was cited by Huller et al. (2017) for the species of E. cloeziana in which, the average value of radial, tangential and longitudinal swelling of the control samples were $8.84,14.79$, and $0.54 \%$, respectively, decreasing to $6.78,9.52$, and $0.48 \%$ when exposed to $210{ }^{\circ} \mathrm{C}$ temperature. This occurrence may be linked to the different basic density values of each species, with denser woods presenting a higher percentage of wall thickness and, thus, a greater site for water absorption (Zaque et al., 2018).

The values of anisotropy coefficient for shrinkage (Table 2) showed that the thermal modification significantly decreased the anisotropic factor (tangential/radial ratio) only for the species $P$. rigida and S. parahyba at the temperature of 180 ${ }^{\circ} \mathrm{C}$, while for $\mathrm{P}$. dubium the decrease was obtained at $150{ }^{\circ} \mathrm{C}$. Regarding the same property, but for swelling (Table 4), it did not differ statistically among all treatments applied to the species E. grandis $\times$ E. urophylla, P. rigida and S. parahyba. For $P$. dubium, there was a decrease in the coefficient at the temperatures of 150 and $210^{\circ} \mathrm{C}$.

According to Poubel et al. (2015), this result is explained due to water absorption in the cell wall, which, is only retained by virtue of the hydroxyl groups. Thus, when the heat treatment is applied they are degraded, hindering absorption, making the wood less hygroscopic and reducing the swelling and anisotropic coefficient values.

Thus, this coefficient is of utmost importance to indicate the shrinkage index, since the higher its value, the greater the dimensional instability, making possible the occurrence of defects, such as the formation of cracks and warping in the wood. Durlo \& Marchiori (1992) employed the anisotropic coefficient for use in construction recommending that values of 1.2 to 1.5 are excellent, 1.5 to 2.0 are taken as normal; and above 2.0 as poor. According to this classification, for shrinkage, only the species $P$. dubium and $E$. grandis $\times E$. urophylla showed a bad index, while for swelling, only $P$. dubium wood is pointed out, the remaining specimens are considered as normal for both properties.

Thus, due to the significant decrease in flexural strength during the four hours for some heat treatments, the use of the woods for structural purposes in civil construction is not suitable. On the other hand, in general, the temperature of $210{ }^{\circ} \mathrm{C}$ provided for all species, except for $P$. dubium, a normal anisotropic coefficient, allowing the application of these woods for external cladding, such as garden furniture, decks, windows, etc. They can also be used internally as kitchen furniture, flooring, bathroom interiors, among other applications.

Table 4. Average values of swelling and anisotropic coefficient of four analyzed species submitted to thermal modification treatment.

\begin{tabular}{|c|c|c|c|c|c|}
\hline \multirow{2}{*}{ Species } & \multicolumn{5}{|c|}{ Treatment } \\
\hline & Control & $120^{\circ} \mathrm{C}$ & $150^{\circ} \mathrm{C}$ & $180^{\circ} \mathrm{C}$ & $210^{\circ} \mathrm{C}$ \\
\hline & & & $\alpha \operatorname{Lg}(\%)$ & & \\
\hline$P$. rigida & $0.52 \mathrm{abA}$ & $0.49 a b A$ & $0.63 \mathrm{Bb}$ & $0.51 \mathrm{abB}$ & $0.37 \mathrm{aA}$ \\
\hline E. grandis $\times E$. urophylla & $0.57 \mathrm{bA}$ & $0.49 \mathrm{bA}$ & $0.37 \mathrm{abA}$ & $0.42 \mathrm{abAB}$ & $0.26 \mathrm{aA}$ \\
\hline S. parahyba & $0.64 \mathrm{bA}$ & $0.30 \mathrm{aA}$ & $0.34 \mathrm{aA}$ & $0.21 \mathrm{aA}$ & $0.23 \mathrm{aA}$ \\
\hline P. dubium & $3.35 \mathrm{bcA}$ & $3.21 \mathrm{bA}$ & $3.83 \mathrm{bcA}$ & $4.37 \mathrm{cA}$ & $1.94 \mathrm{aA}$ \\
\hline E. grandis $\times E$. urophylla & $8.39 \mathrm{dC}$ & $7.95 \mathrm{cdB}$ & $6.29 \mathrm{bB}$ & $7.21 \mathrm{bcB}$ & $4.04 \mathrm{aB}$ \\
\hline \multirow[t]{2}{*}{ S. parahyba } & $3.18 \mathrm{bA}$ & $3.71 \mathrm{bA}$ & $3.83 \mathrm{bA}$ & $3.29 \mathrm{bA}$ & $1.83 \mathrm{aA}$ \\
\hline & & & $\alpha \operatorname{Rd}(\%)$ & & \\
\hline$P$. rigida & $3.13 \mathrm{bB}$ & $3.76 \mathrm{cB}$ & $3.63 \mathrm{bcB}$ & $3.44 \mathrm{bcB}$ & $2.14 \mathrm{aB}$ \\
\hline$P$. rigida & $2.27 \mathrm{bA}$ & $2.18 \mathrm{bA}$ & $1.90 \mathrm{aA}$ & $2.23 \mathrm{bA}$ & $1.88 \mathrm{aA}$ \\
\hline P. dubium & $2.17 a b A$ & $1.94 \mathrm{aA}$ & $2.21 \mathrm{bB}$ & $2.16 \mathrm{abA}$ & $2.31 \mathrm{bB}$ \\
\hline E. grandis $\times E$. urophylla & $2.09 \mathrm{aA}$ & $2.09 \mathrm{aA}$ & $1.97 \mathrm{aAB}$ & $2.02 \mathrm{aA}$ & $1.96 \mathrm{aA}$ \\
\hline S. parahyba & $2.23 \mathrm{bA}$ & $1.94 \mathrm{aA}$ & $2.00 \mathrm{abAB}$ & $2.00 \mathrm{abA}$ & $1.94 \mathrm{aA}$ \\
\hline
\end{tabular}

Where: $\alpha$ Lg: Longitudinal swelling (\%); $\alpha$ Tg: Tangential swelling (\%); $\alpha$ Rd: Radial swelling (\%); Ca $\alpha$ : Anisotropic swelling coefficient. Lower case letters in the row compare temperature treatments and upper case letters in the columns compare species, according to Tukey test at $5 \%$ error probability. 


\section{Conclusions}

The heat treatments alters the physical and mechanical properties of the four species studied.

The technical treatment modifies the mechanical properties of wood in a positive way up to $180^{\circ} \mathrm{C}$. The highest values of the mechanical properties are observed for the species $E$. grandis $\times E$. urophylla and $P$. rigida.

The technical treatment modifies the dimensional stability of the wood in a positive way up to $210{ }^{\circ} \mathrm{C}$. The values of the anisotropic coefficient of wood decrease with increasing temperature.

The dimensional variation in the longitudinal direction is less than the variation in the radial and tangential directions.

The basic density influences the mechanical properties of wood, and the species $P$. rigida presents the highest values.

\section{Compliance with Ethical Standards}

Author contributions: Conceptualization: $E B, E E, R T$, TSM, LSZ, LC, NEPA, YCTS; Formal analysis: VFCM, LVS, EDG; Investigation: EB, EE, RT, TSM, LSZ, LC, NEPA, YCTS; Writing original draft: EB, EE, RT, TSM, LSZ, LC, NEPA, YCTS; Writing review \& editing: EB, EE, RT, TSM, LSZ, LC, NEPA, YCTS.

Conflict of interest: The authors declare that they have no conflict of interest.

Funding: This study was supported by the Conselho Nacional de Desenvolvimento Científico e Tecnológico (CNPq).

\section{Literature Cited}

American Society for Testing and Materials - ASTM. Standard methods of testing small clear specimens of timber: ASTM D 14394. West Conshohocken: ASTM, 2000. 31p. Associação Brasileira de Normas Técnicas - ABNT. NBR 7190: projeto de estruturas de madeira. Rio de Janeiro: ABNT, 1997. 107p.

Braz, R.L.; Duarte, A.P.C.; Oliveira, J.T.D.S.; Motta, J.P.; Rosado, A.M. Curva característica de secagem da madeira de Tectona grandis e Acacia mangium ao ar livre. Floresta e Ambiente, v.22, n.1, p.117-123, 2015. https://doi.org/10.1590/2179-8087.037913.

Cademartori, P.H.G.; Schneid, E.; Gatto D.A.; Beltrame, R.; Stagerlin, D.M. Modification of static bending strength properties of Eucalyptus grandis heattreated wood. Materials Research, v.15, n.6, p.922-927, 2012. https://doi.org/10.1590/S151614392012005000136.

Carvalho, D.E.; Juizo, C.G.F.; França, M.C.; Loiola, P.L.; Rocha, M.P. Efeito da modificação térmica na resistência natural da madeira Eucalyptus grandis e Pinus taeda. Revista Brasileira de Ciências Agrárias, v.14, n.1, e5606, 2019. https://doi.org/10.5039/agraria. v14i1a5606.

Cezaro, J.A.; Trevisan, R.; Balbinot, R. Propriedades físicomecânicas da madeira de Chrysophyllum marginatum. Pesquisa Florestal Brasileira, v.36, n.86, p.135-146, 2016. https://doi. org/10.4336/2016.pfb.36.86.884.

Durlo, M.A.; Marchiori, J.N.C. Tecnologia da madeira: retratibilidade. Santa Maria: CEPEF; FATEC, 1992. 33p.
Eleotério, J.R.; Reichert, D.; Hornburg, K.F.; Meneguelli, I. Massa específica e retratabilidade da madeira de seis espécies de eucalipto cultivadas no litoral de Santa Catarina. Floresta, v.45, n.2, p.329-336, 2015. https://doi.org/10.5380/rf.v45i2.34699.

Esteves, B.M.; Pereira, H.M. Wood modification by heat treatment: a review. BioResources, v.1, n.4, p.370-404, 2009. https://ojs.cnr.ncsu.edu/index.php/BioRes/article/view/ BioRes_04_1_\%23\%23\%23\%23_Esteves_P_Wood_Mod_Heat_ Treatment/350. 28 Jul. 2020.

Ferreira, M.S.; Melo, R.R.; Zaque, L.A.; Stangerlin, D.M. Propriedades físicas e mecânicas da madeira de angelim-pedra submetida a tratamento térmico. Tecnologia em Metalurgia, Materiais e Mineração, v.16, n.1, p.3-7, 2019. https://doi.org/10.4322/21761523.20191297.

Fontoura, M.R.; Geraldi, V.; Rodrigues, E.F.; Moi, C.C.; Cerutti, G.C.; Thiel, B.R.; Trevisan, R.; Wastowski, A.D. Propriedades mecânicas e químicas da madeira de Hovenia dulcis Thunberg. tratada termicamente. Ciência da Madeira, v.6, n.3, p.166-175, 2015. https://doi.org/10.15210/cmad.v6i3.7138.

Gallio, E.; Zanatta, P.; Cruz, N.D.; Zanol, G.S.; Schulz, H.R.; Gatto, D.A. Influência dos tratamentos de termorretificação e furfurilação em propriedades tecnológicas de uma conífera. Matéria, v.24, n.3, e12424, 2019. https://doi.org/10.1590/s1517707620190003.0739.

Huller, L.A.S.; Haselein, C.R.; Silveira, A.G.; Menezes, W.M.; Talgatti, M.; Souza, J.T.; Santini, E.J. Modificação térmica e propriedades tecnológicas da madeira de Eucalyptus cloeziana. Pesquisa Florestal Brasileira, v.37, n.90, p.183-188, 2017. https://doi. org/10.4336/2017.pfb.37.90.1288.

Mbamu, M.F.A. de O.; Nascimento, A.M. do; Garcia, R.A.; Jesus, D.S. de. Propriedades mecânicas em duas espécies de bambu submetidas a tratamentos térmicos. Cadernos de Ciência \& Tecnologia, v.37, n.1, p. 1-8, 2020. https://doi.org/10.35977/0104-1096.cct2020. v37.26547.

Modes, K.S.; Santini, E.J.; Vivian M.A.; Haselein, C.R. Efeito da termorretificação nas propriedades mecânicas das madeiras de Pinus taeda e Eucalyptus grandis. Ciência Florestal, v.27, n.1, p.291-302, 2017. https://doi.org/10.5902/1980509826467.

Paes, J.B.; Segundinho, P.G.D.A.; Euflosino, A.E.R.; Silva, M.R.D.; Calil Jr, C.; Christoforo, A.L. Biological resistance of thermally treated Corymbia citriodora (Hook.) K.D. Hill \& L.A.S. Johnson and Pinus taeda L. woods against xylophagous termites. Revista Árvore, v.40, n.3, p.535-541, 2016. https://doi.org/10.1590/010067622016000300017.

Paneque, L.N.; Lima, I.S. de; Florsheim, S.M.B.; Sakita, M.N. Temperatura de modificação térmica em algumas propriedades e características da madeira de Eucalipto. Scientia Agraria Paranaensis, v. 18, n.1, p.15-21, 2016. http://131.255.84.97/ index.php/scientiaagraria/article/viewFile/20840/14090. 22 Jul. 2020.

Paula, M.H. de; Mesquita, R.R.S. de; Gonçalez, J.C.; Ribeiro, E.S.; Souza, R.S. Utilização de métodos não destrutivos para caracterização simplificada da madeira de cumaru (Dipteryx odorata Willd). Biodiversidade, v.15, n.2, p.136-149, 2016. http://www.periodicoscientificos.ufmt.br/ojs/index.php/ biodiversidade/article/view/3967/2761. 17 Jul. 2020. 
Poubel, D.S.; Garcia, R.A.; Santos, W.A.; Lelis, R.C.C.; Vieira, L.A.A. Análises físicas e colorimétricas da madeira de Pinus sp. modificada termicamente. Scientia Forestalis, v.43, n.107, p.511521, 2015. https://www.ipef.br/publicacoes/scientia/nr107/ cap02.pdf. 14 Jun. 2020.

Rocha, M.F.V.; Vital, B.R.; Carneiro, A.C.O.; Carvalho, A.M.M.L.; Cardoso, M.T.; Hein, P.G. Effects of plant spacing on the physical, chemical and energy properties of Eucalyptus wood and bark. Journal of Tropical Forest Science, v.28, n.3, p.243-248, 2016. https://www.jstor.org/stable/43856528. 17 Jul. 2020.

SAS Institute - SAS. Getting started with the SAS Learning Edition. Cary, SAS, 2003. 81p.

Schulz, H.R.; Acosta, A.P.; Barbosa, K.T.; Gallio, E.; Beltrame, R.; Gatto, D.A. Efeito do tratamento térmico da madeira de Pinus elliottii nos parâmetros físico-mecânicos e colorimétricos. Biofix Scientific Journal, v.5, n.1, p.86-93, 2020. https://doi.org/10.5380/biofix. v5i1.68111.
Silva, M.R. da; Brito, J.O.; Govone, J.S.; Machado, G. de O.; Calil, C.; Christoforo, A.L.; Lahr, F.A.R. Chemical and mechanical properties changes in Corymbia citriodora wood submitted to heat treatment. International Journal of Materials Engineering, v.5, n.4, p.98-104, 2015. https://doi.org/10.5923/j.ijme.20150504.04.

Souza, K.; Higuchi, P.; Silva, A.C.D.; Schimalski, M.B., Loebens, R.; Buzzi $J r, F . ;$ Rosa, A.D. Partição de nicho por grupos funcionais de espécies arbóreas em uma floresta subtropical. Rodriguésia, v.68, n.4, p.11651175, 2017. https://doi.org/10.1590/2175-7860201768401.

Trevisan, R.; Zanella, A.; Silva, F.M. da; Rosa, M.; Fioresi, T.; Fortes, F.D.O. Axial variation of basic density of Araucaria angustifolia wood in different diameter classes. Ciência Rural, v.46, n.11, p.1969-1972, 2016. https://doi.org/10.1590/0103-8478cr20141312.

Zaque, L.A.M.; Ferreira, M.D.; Melo, R.R. Variação radial e longitudinal da massa específica básica da madeira de Araucaria angustifolia com diferentes idades. Pesquisa Florestal Brasileira, v.38, e201601368, 2018. https://doi.org/10.4336/2018.pfb.38e201601368. 